Nataliia Pavliuk

https://orcid.org/0000-0003-3451-1063

\title{
PRONOMINAL ADVERBS OF ENGLISH LEGAL DISCOURSE TRANSLATED INTO UKRAINIAN: SEMANTIC, MORPHOLOGICAL AND SYNTACTIC DIMENSIONS
}

The paper studies specific features of English pronominal pronouns and their translation. The results of the research show that the compounds in question are the archaic feature of the English legalese, they appeared in the Old English period, the same time as the adverbs here and there emerged, and some of them came into use in the Middle English time. The pronominal character of pronominal adverbs (PAs) is clearly seen through the lens of Ukrainian translation where they are mostly rendered by means of pronouns or noun phrases. Since Ukrainian does not have direct equivalents for English PAs, we can see ten different means used to translate them into Ukrainian.

Keywords: legal discourse, pronominal adverbs, legal English, semantics, case system, archaism.

\section{Introduction}

Legal discourse is characterized by different linguistic and extra-linguistic features, and for the English legal language the archaisms are bright signals of the style and discourse in general. Pronominal adverbs (PAs), the compounds that have an adverb as a constituent part with pronominal features, here-/therePAs, appeared in the English language in the Old English period. They were introduced into the English legalese the moment the first legal documents appeared, and are still found in English legal texts. Their study from the translation perspective is challenging as Ukrainian has no full equivalents of such compounds. The paper is aimed at studying specifics of translating PAs from English into Ukrainian. The objectives set in the paper are to study the means of translation, the correlation between the role of the preposition within English pronominal adverbs and the cases of Ukrainian pronouns and nouns in the target text, reveal the problems of uncertainty and ambiguity created by the 
pronominal adverbs in question, research the semantics and morphological status of the compounds.

\section{Theoretical Background}

The studies of pronominal adverbs have been conducted not only within the research of legal English in general, but also concerning the translation of legal texts from English into different languages. It is accounted for by the fact that the phenomenon in question is a characteristic feature of the English legal discourse, it is one of the other archaic features still found in the English legalese. The matter of archaic lexical and grammatical characteristics was covered by the researchers studying legal translation (S. Šarčević, D. Reed, B. Kielar, R. Wydick). The pronominal adverbs under study are compounds of ancient origin, most of which were formed in the Old English period. In their structure they contain an adverb with pronominal meaning and perform syntactic functions of nominal word-groups (substantives, pronouns, adjectives), which needs to be studied as well. Grammatical features of pronominal adverbs containing here-/there-elements are of special interest for the study of grammatical problems of translating legal texts from English and Ukrainian, as such lexemes are not found in Ukrainian. The translation of the pronominal adverbs into Ukrainian helps understand their function and meaning, methods of translation are based on the connection of the pronominal adverb with the noun or the noun-phrase it is used to replace. So, this study presents a multi-aspect investigation of the phenomenon, typical of the English legal discourse, called pronominal adverbs. The purpose of the paper is to study the dual nature of the pronominal adverbs containing here-/there-elements from semantic, syntactic and stylistic perspectives.

\section{Methodology and Methods}

For the purpose of the paper the pronominal adverbs containing here-/ there-elements of $33 \mathrm{EU}$ Regulations translated from English into Ukrainian were studied, the general number of the phenomena in question being 325 . In order to analyse the pronominal adverbs the corpus of the above-mentioned Regulations and their translation was compiled and analysed with the help of SketchEngine software which allowed to obtain the precise quantitative information about the frequency and productivity of the use of the pronominal adverbs. It shows the exact number of PAs used in the analysed documents. The sentences containing pronominal adverbs in question were selected out 
of the texts by the method of continuous sampling, the transformational analysis was applied to prove the pronominal character of the studied lexemes by replacing the pronominal element of the compound by the noun or the noun phrase it stands for, the componential semantic analysis was used to study the semantics of the both elements of the compounds, the descriptive method helped to explicate the nature and origin of the phenomenon in question.

\section{Origin and development of Pronominal Adverbs as a feature of English Legalese}

The pronominal adverbs herein, hereafter, thereby, thereto and the like belong to the archaic elements of English legalese, being its characteristic feature. Since they appeared in the Old and Middle English period it is worth studying the history of their emergence and introduction to the legal discourse. The pronominal adverbs consist of two, sometimes three elements (here + in/ after/under, here + in + after, there + in/after/under/to/by), so first there should have appeared the meaningful elements of the compound, i. e. here and there. According to the etymological dictionaries, these adverbs appeared during the Old English period:

here (adv.): Old English her "in this place, where one puts himself; at this time, toward this place",

there (adv.): Old English paer "in or at that place, so far as, provided that, in that respect".

As we can see, the primary meaning of the adverbs is pointing to a place, a closer or a farther one. The etymology of the compounds reveals that they appeared in English either in the Old English time: hereupon, hereon, herein, herewith, hereof, hereafter, thereafter, thereby, therein, thereto, thereunder, or in the Middle English period: hereunder, hereto, hereby, hereabout, heretofore. The pronominal features were obtained by the compounds at that period, as their explications contain the pronouns 'that', 'this', etc. E. g.

hereunder (adv.) "under this," early $15 \mathrm{c}$., from here + under.

hereupon (adv.) "upon this," late Old English, from here + upon.

The question rises when these compounds began to be used in English legalese. From the time of their origin it is possible to presume that they have always been a specific feature of the English legal discourse. G. di Carlo mentions the first Act of Parliament the English legalese dates back to, "The first Act of Parliament written in English dates back to 1483; however, English became the language of legal institutions only after two centuries, 
with the Act for Turning the Books of Law and all Processes and Proceedings in Court of Justice in English (1650) (Vystrcilova, R. 2000: 73). The form of English used after the Norman Conquest until 1475 was Middle English. It is the period where words such as 'notwithstanding', 'aforesaid', 'whereas', 'whereby', 'whereupon', 'hereby', 'therefore', and 'alike', flourished. During the $16^{\text {th }}$ century, English rapidly expanded, especially in the field of the legal profession" (Di Carlo, 2015, p. 24) Legal English is characterized by its old or 'antiquated vocabulary' (Alcaraz Varò and Hughes, 2002, p. 5). It dates back to Old and Middle English. The former refers to the period prior to the Norman Conquest ( $5^{\text {th }}$ century to 1066 ). In this period, the Celtics, Anglo-Saxons, and Christians loaded the language of law with archaic terms such as 'hereafter' and 'herein'. Middle English covers the period from after the Norman Conquest (1100-1500). The most common forms of archaic vocabulary are 'hereby', 'thereby', 'aforesaid', 'said', 'thereby', and 'hereof'. The adverbs often refer to the text or document in which they appear or the one under discussion." (H. El-Farahaty, 2011, p. 61).

It is important to stress that the status of the compounds in question needs studying, as we can notice that different researchers use various terms. Thus, for instance Di Carlo speaks of the conjunctions including the compounds with here-/there-element, "Another element of cohesion that reveals a distinctive sign of conservationism in Legal English is conjunction. Some examples of antiquated legalese conjunctions are 'hereto', 'aforesaid', 'hereby', 'hereinafter', 'hereof', 'whosoever', 'thereof', and 'therein'"(Carlo, 2015, p. 34). The fact that some of them, like therefore really lost their adverbial and pronominal characteristics and acquired the status of a conjunction does not make it possible to speak of them all as of conjunctions, which is proven by the analysis of their pronominal features below in this paper.

The structure of pronominal adverbs determines their complex semantic structure. Ludiková studied the pronominal adverbs in the Czech language and pointed out, "The semantics of pronominal adverbs is of a complex character including two major components. There is, first, a pronominal meaning - deictic, relative, indefinite, interrogative, and negative, and second, a meaning of circumstance, i.e. that of place, of time, and of manner. The interaction of the two meaning components makes the semantics of pronominal adverbs easily subject to modifications in dependence on whether the circumstantial or the pronominal component is enforced. The circumstantial meaning may be present in various shades, varying extent and intensity, may be general or specific. 
The same adverb may be a full word or a more or less empty word keeping only its pronominal meaning; in this case the adverb appears to be on the way of transition to participles or conjuntions." (Ludiková, 1987, p. 43)

In English pronominal adverbs with here-/there-elements this dual meaning is observed as well. As mentioned before, these elements had the primary meaning of place determiners which transformed under the influence of the second element (preposition) into a noun or a noun phrase substitutes. Deictic, relative and indefinite are all characteristics that may be attributed to the pronominal adverbs in questions.

V. Ozhohan explained the transposition of one word-group into another as follows, "The transposition, i. e. the transfer of one a word from one wordgroup to another, is caused by several factors, including the following: 1) the use of a word in a syntactic function, it usually does not perform (position shift); 2) the reduction of the component the source word is subordinate to (or correlates with); 3) the morphological change of the component linked to it grammatically; 4) the change of the syntactic function." (Ожоган, 2016, p. 17)

All the above-mentioned factors are true for the adverbs to acquire pronominal features. "In the language, apart from substantivation, adjectivation, verbalization and adverb alization (unquestionable transformation representatives), there is also pronominalization, i. e. the transposition of other parts of speech into pronouns. Taking into account the fact that pronouns are often considered as parts of core parts of speech, that is nouns, adjectives and adverbs, it would be reasonable to differentiate between noun pronominalization, adjective pronominalization and adverbial pronominalization. The transposition to pronouns is usually caused by the lost or weakened lexical or nominative meaning and gained generalized abstract deictic function (such words get to be used as sinsemantic units, i. e. units with relative meaning." (Ожоган, 2016, p. 17)

The status of the compounds with there- / here- elements needs clarifying, as soon as they have double nature. From the lexical point, they are used to replace a noun or a noun phrase, which proves their pronominal character. In order to find out, if the pronominal or adverbial grammatical meaning prevails in the compounds in question, and correspondingly find out which term is the best to denominate this phenomenon, it is necessary to analyse their syntactic function as one of the most important formal characteristics used to find out which word-group a word belongs to. Adverbs are usually found in the function of an adverbial modifier, while pronouns being the 
nominative word-group, perform nominative functions in the sentence, i. e. the functions of the attribute and the object. Looking at English sentences containing the compounds in question one may say they perform the function of an adverbial modifier of place or manner (as well as their main elements do) modifying the verb they are subordinate, e. g.

Both the Commission and the body shall be able to terminate the agreement without cause at the expiry of a reasonable period of notice to be defined therein.

(Regulation of European Commission 1007/2011)

It thereby enhances the principle of mutual recognition ...

(Regulation of European Commission $765 / 2008$ )

National authorities shall recognise the equivalence of the services delivered by those accreditation bodies which have successfully undergone peer evaluation under Article 10, and thereby accept... the accreditation certificates...

(Regulation of European Commission 765/2008)
I Комісія, й орган мають змогу розірвати договір без зазначення причини після завершення розумного періоду повідомлення, визначеного у договорі.

(Регламент Європейської комісії 1007/2011)

Вона у такий спосіб підсилює дію принципу взаємного визнання... (Регламент Свропейської комісії 765/2008)

Національні органи визнають рівнозначність послуг, наданих такими органами з акредитаціï, які успішно пройшли взаємне оиінювання відповідно до статті 10, і у такий спосіб приймають ... сертифікати про акредитаиію... (Регламент Європейської комісії $765 / 2008)$

Having analysed the pronominal adverbs thereto, thereof, thereafter, therein, therefrom, thereby, thereon, therefor, herein, here(in)after, hereunder, found in the Regulations, the conclusion was made that only thereby, thereon and herein modify a verb and function as adverbial modifiers, while the rest modify a noun and perform attributive function, e. $g$.

The recognised organisation must have and apply a set of own comprehensive rules and procedures, or the demonstrated ability thereto, for the design...

(Regulation of European Commission 391/2009)
Визнана організація повинна мати та застосовувати власний набір комплексних правил та процедур або демонструвати можливість мати такі правила і процедури щзодо проєктування... (Регламент Європейської комісії 391/2009) 
...provided for in that Decision should, with the exception of the regulatory procedure with scrutiny provided for in Article 5 a thereof, ...

(Regulation of European Commission 765/2008) ...nередбачені у вказаному Ріменні, повинно, за винятком регуляторної проиедури з ретельним вивченням, передбаченої в статті 5 а того ж Рішення,... (Регламент Свропейської комісії $765 / 2008)$

Ukrainian translation of the compounds confirms the dominance of the pronominal component of meaning in the phenomenon under study. As long as the Ukrainian language does not have full equivalent of such compounds, translators choose different methods of rendering them which will be discussed below. Right now, it is important to stress that all means of translating the compounds into Ukrainian are nominal, i. e. pronouns (personal or demonstrative), pronominal phrases, nouns and noun phrases (see Table 1). From this it follows that the pronominal component of grammatical meaning of these compounds dominates, which means this word group might as well be named 'adverbial pronouns'.

The pronominal character of the lexical units in question is determined by their meaning and function. Upon combining with a certain preposition they form a compound lexical unit having the meaning of the replaced noun and functioning as attribute or adverbial modifier in the sentence. All three aforesaid types of PAs are characterized by different meanings, though all of them can be substituted by a certain prepositional noun phrase containing the preposition, which is a constituent part thereof.

Thus, the element here- stands for the whole document where it is used or for its article or clause, e. g.

Under the body's constitution, national accreditation bodies from within the Community shall be entitled to be members of it, provided that they comply with the rules and objectives of the body and with the other conditions set out herein and as agreed with the Commission in the framework agreement. (Regulation of European Commission 765/2008).

Here-element stands for the Regulation the PA herein is used in, and can be paraphrased as 'in this Regulation', 'in this document'.

The element there-stands for the noun found in the same sentence or in the previous one, e. g.

Any committee member who does not oppose the draft implementing act or who does not explicitly abstain from voting thereon before the expiry of that 
time limit shall be regarded as having tacitly agreed to the draft implementing act. (Regulation of European Commission 182/2011).

'There'-element stands for the 'draft implementing act', and the whole compound can be paraphrased as 'on that', 'on this act', etc.

"So a pronominal adverb with here-/there-elements can be paraphrased into 'preposition + this/that' phrase, where 'this/that' stands for the whole document in case of here- and for the component of the same or the previous sentences in case of there-PA. Besides, it can be seen that in such paraphrased expressions, the last part, whose specific meaning indicated by the demonstratives 'this' or 'that' within the phrase "this/that/which..." calls for more relevant contextual information for its precise interpretation, which indicates, to put it in a simple way, that the meaning of a pronominal adverb is not fixed, but may change as it is employed in different contexts". (Geng, 2018, p. 118)

Speaking about there-PAs, they can stand for more than one noun or noun phrase, but also for a set of nouns or noun phrases, meaning that there-compounds may express plurality. So, the scheme presented above may be completed by "preposition + these/those" pattern, which implies that there can stand for both singular and plural.

Such reviews and assessments shall be carried out at least every fourth year and the results thereof shall be communicated to the other Member States and the Commission and be made available to the public, by way of electronic communication and, where appropriate, by other means.

(Regulation of European Commission 765/2008)
Такі перегляди й очінювання здійснюють щонайменше раз на чотири роки, а про їх результати повідомляють інші держави-члени і Комісію та доводять до відома громадськості за допомогою засобів електронної комунікаиії та, у відповідних випадках, інших засобів.

(Регламент Європейської комісії $765 / 2008)$

As long as the pronominal adverbs with here-/there- elements do not have any signs of number, gender or case (in contrast to Ukrainian pronouns), their meaning may be ambiguous and uncertain, preventing readers from identifying easily, which sentence component they substitute as pronominal units. In several sentences under consideration the pronominal adverb may stand for either one noun, a noun phrase or homogeneous nouns (see the above examples). 
The ambiguity or uncertainty is also accounted for by the fact that the word order which usually helps in English compensate the lack of an inflexion system of nouns and other word groups, brings here more complexity to understanding the whole sentence. As the studied factual material shows, the pronominal adverbs containing there-element are found in the end of the phrase or, even more often, in the end of the whole sentence, the recipient may find it difficult to identify which part of the sentence is replaced by the pronominal adverb in question: either one word or a group of homogeneous parts of the sentence, or a name of the document.

\section{Translation techniques applied to translate pronominal adverbs from English into Ukrainian}

To study the translation of the pronominal adverbs, the EU Regulations (33 documents, 282770 words, including 264 pronominal adverbs) and their translation into Ukrainian were analysed. The means of translation used to render pronominal adverbs from English into Ukrainian are one-component and multi-component. The one-component equivalents include individual pronouns (personal or possessive), with more specific grammatical characteristics than the source word, as they have the categories of number, gender and case, which makes it easier to identify the noun (noun phrase) replaced by the pronominal adverb in question.

The prepositional part of the pronominal pronouns requires special attention. Its use is determined by the following: 1) the rules of government of the word modified (which preposition is required, case government etc.); 2) the relations between the objects in question (lacking a morphologically expressed case system, English makes extensive use of prepositions for showing the relations between objects). So, in the Ukrainian translation the grammatical meaning of the prepositional part is rendered by means of cases (both of pronouns and nouns used for translation). For example, in the following sentence thereof contains the prepositional part 'of' which corresponds to the genitive case, which is illustrated by the pronoun 'таких' (genitive case, plural) used to translate 'thereof' into Ukrainian, e. g. 
Member States shall establish procedures for the resolution of appeals, including, where appropriate, legal remedies against accreditation decisions or the absence thereof. (Regulation of European Commission 765/2008)
Держави-члени встановлюють процедури врегулювання оскаржень, у тому числі, у відповідних випадках, засоби правового захисту від рішень щзодо акредитації або відсутності таких.

(Регламент Свропейської комісії $765 / 2008)$

The main relations between the objects manifested by the use of certain prepositions are as follows: - locative (in); - temporal (after); - possessive (of); - instrumental (by, upon). As long as there are no or scarce formal means of case expression in English, it would be natural to consider the category to be semantic rather than morphological one. Understanding the relations between the objects or the action and the object expressed with the help of prepositions in English is important for translating the PAs. As soon as the aforesaid lexical units are characteristic of the modern legal English, one should clearly understand the relations within the sentence they express for rendering them correctly while translating legal documents.

Since the case system is well-developed in Ukrainian, each of the PAs comprising a prepositional element is translated with the help of a noun or pronoun in the relevant case, determined by the headword, a verb or a noun. As has been mentioned above, thereby, thereon and herein modify verbs, and as a result, their adverbial characteristics are stronger than in other PAs in question. Though in translation, only thereby and thereafter preserve their adverbial character in Ukrainian, being translated as ' $y$ такий спосіб, у результаті чого, надалі, після иього'. The rest PAs found in the studied Regulations are translated with the help of pronouns, pronoun phrases, adjectives, or noun phrases.

The total number of pronominal adverbs in the analysed Regulations is 11 (264 uses), among them thereof (82), thereto (38), therein (39), thereafter (30), thereby (15), thereon (3), therefor (3), hereby (21), hereinafter (21), herein (6), hereunder (6). The translation means are represented in the Table 1 below, demonstrating that the most frequently used means of translation is possessive pronouns, accounted for by the fact that the most frequently used pronominal adverb is thereof, where of has the meaning of the Possessive Case, which is rendered into Ukrainian with the help of a possessive pronoun or a noun in genitive case. 
Table 1

Means of PA Translation from English into Ukrainian

\begin{tabular}{|c|c|c|c|c|c|}
\hline & $\begin{array}{c}\text { Means } \\
\text { of Translation }\end{array}$ & Source & Target & $\begin{array}{c}\text { Quan- } \\
\text { tity }\end{array}$ & $\%$ \\
\hline \multicolumn{6}{|c|}{ One-Component } \\
\hline 1 & $\begin{array}{l}\text { Possessive } \\
\text { Pronoun }\end{array}$ & $\begin{array}{l}\text { Where reference is made } \\
\text { to this paragraph, Articles } \\
5 \mathrm{a} \text { and } 7 \text { of Decision } 1999 / \\
468 / \mathrm{EC} \text { shall apply, having } \\
\text { regard to the provisions } \\
\text { of Article } 8 \text { thereof }\end{array}$ & $\begin{array}{l}\text { У разі покликання на цей } \\
\text { параграф, застосовуються } \\
\text { статті 5а і } 7 \text { Рішення 1999/ } \\
\text { 468/ЄС з урахуванням } \\
\text { положень його статті } 8\end{array}$ & 93 & 35.2 \\
\hline 2 & $\begin{array}{l}\text { Personal } \\
\text { Pronoun }\end{array}$ & $\begin{array}{l}\text { activities in respect of } \\
\text { which it operates accredi- } \\
\text { tation and any changes } \\
\text { thereto }\end{array}$ & $\begin{array}{l}\text { види діяльності з оцінюван- } \\
\text { ня відповідності, акредита- } \\
\text { цію яких він проводить, } \\
\text { та про будь-які зміни у них }\end{array}$ & 66 & 25 \\
\hline 3 & $\begin{array}{l}\text { Demon- } \\
\text { strative } \\
\text { Pronoun }\end{array}$ & $\begin{array}{l}\text { Member States shall } \\
\text { establish procedures for } \\
\text { the resolution of appeals, } \\
\text { including, where appropri- } \\
\text { ate, legal remedies against } \\
\text { accreditation decisions or } \\
\text { the absence thereof }\end{array}$ & $\begin{array}{l}\text { Держави-члени встановлю- } \\
\text { ють процедури врегулю- } \\
\text { вання оскаржень, у тому } \\
\text { числі, у відповідних випад- } \\
\text { ках, засоби правового за- } \\
\text { хисту від рішень щодо акре- } \\
\text { дитації або відсутності таких }\end{array}$ & 15 & 5.6 \\
\hline \multicolumn{6}{|c|}{ Multi-Component } \\
\hline 4 & $\begin{array}{l}\text { (Prep) + } \\
\text { Pron + N }\end{array}$ & $\begin{array}{l}\text { It thereby enhances the } \\
\text { principle of mutual recog- } \\
\text { nition and therefore the } \\
\text { provisions of this Regula- } \\
\text { tion on accreditation } \\
\text { should apply in relation } \\
\text { to bodies carrying out } \\
\text { conformity assessments } \\
\text { in both the regulated and } \\
\text { the non-regulated areas }\end{array}$ & $\begin{array}{l}\text { Вона у такий спосіб під- } \\
\text { силює дію принципу вза- } \\
\text { ємного визнання, тому } \\
\text { положення цього Регла- } \\
\text { менту щодо акредитації } \\
\text { необхідно застосовувати } \\
\text { до органів, які здійснюють } \\
\text { оцінювання відповідності } \\
\text { як у регульованій, так і } \\
\text { в нерегульованій сферах }\end{array}$ & 57 & 21.6 \\
\hline 5 & $\begin{array}{l}\text { Adverbial } \\
\text { Phrase }\end{array}$ & $\begin{array}{l}\text { If action has been taken } \\
\text { without the operator's } \\
\text { being heard, the operator } \\
\text { shall be given the opportu- } \\
\text { nity to be heard as soon as } \\
\text { possible and the action } \\
\text { taken shall be reviewed } \\
\text { promptly thereafter }\end{array}$ & $\begin{array}{l}\text { Якщо захід вжито без } \\
\text { вислуховування позиції } \\
\text { суб'єкта, то суб'єкт по- } \\
\text { винен отримати можли- } \\
\text { вість висловити свою } \\
\text { позицію якнайшвидше; } \\
\text { після цього захід негайно } \\
\text { переглядають }\end{array}$ & 9 & 3.5 \\
\hline
\end{tabular}


Continuation of Table 1

\begin{tabular}{|c|c|c|c|c|c|}
\hline & $\begin{array}{c}\text { Means } \\
\text { of Translation }\end{array}$ & Source & Target & $\begin{array}{c}\text { Quan- } \\
\text { tity }\end{array}$ & $\%$ \\
\hline 6 & Adjective & $\begin{array}{l}\text { By } 1 \text { January } 2013 \text {, and } \\
\text { every five years thereafter, } \\
\text { the Commission, in cooper- } \\
\text { ation with the Member Sta- } \\
\text { tes, shall produce and sub- } \\
\text { mit to the European Parlia- } \\
\text { ment and to the Council } \\
\text { a report on the implementa- } \\
\text { tion of this Regulation }\end{array}$ & $\begin{array}{l}\text { До } 1 \text { вересня } 2013 \text { року } \\
\text { і щоп'ять наступних років } \\
\text { Комісія, у співпраці з дер- } \\
\text { жавами-членами, складає } \\
\text { і подає до Європейського } \\
\text { Парламенту і Ради звіт } \\
\text { про імплементацію цього } \\
\text { Регламенту }\end{array}$ & 9 & 3.5 \\
\hline 7 & $\begin{array}{l}\text { Participial } \\
\text { Phrase }\end{array}$ & $\begin{array}{l}\text { Where a national accredi- } \\
\text { tation body does not meet } \\
\text { the requirements of this } \\
\text { Regulation or fails to fulfil } \\
\text { its obligations hereunder, } \\
\text { the Member State } \\
\text { concerned shall take } \\
\text { appropriate corrective } \\
\text { action or shall ensure that } \\
\text { such corrective action is } \\
\text { taken, and shall inform the } \\
\text { Commission thereof }\end{array}$ & $\begin{array}{l}\text { кщо національний орган } \\
\text { з акредитації не відповідає } \\
\text { вимогам цього Регламенту } \\
\text { або не виконує свої обов'яз- } \\
\text { ки, передбачені у цьому } \\
\text { Регламенті, відповідна } \\
\text { держава член вживає на- } \\
\text { лежних коригувальних } \\
\text { заходів або забезпечує } \\
\text { вжиття таких коригуваль- } \\
\text { них заходів та повідомляє } \\
\text { про таке Комісію }\end{array}$ & 6 & 2.3 \\
\hline 8 & $\begin{array}{l}\text { Infinitive } \\
\text { Phrase }\end{array}$ & $\begin{array}{l}\text { The recognised organisa- } \\
\text { tion must have and apply a } \\
\text { set of own comprehensive } \\
\text { rules and procedures, or } \\
\text { the demonstrated ability } \\
\text { thereto, for the design, } \\
\text { construction and periodic } \\
\text { survey of merchant ships, } \\
\text { having the quality of } \\
\text { internationally recognised } \\
\text { standards }\end{array}$ & $\begin{array}{l}\text { Визнана організація по- } \\
\text { винна мати та застосовува- } \\
\text { ти власний набір комплек- } \\
\text { сних правил та процедур } \\
\text { або демонструвати можли- } \\
\text { вість мати такі правила } \\
\text { і процедури щодо проєкту- } \\
\text { вання, побудови та періо- } \\
\text { дичного огляду торговельних } \\
\text { суден, якість яких відпові- } \\
\text { дає визнаним на міжнарод- } \\
\text { ному рівні стандартам }\end{array}$ & 3 & 1.1 \\
\hline 9 & Prep $+\mathrm{N}$ & $\begin{array}{l}\text { A decision to revoke shall } \\
\text { put an end to the delegation } \\
\text { of the power specified in that } \\
\text { decision. It shall take effect } \\
\text { the day following its publi- } \\
\text { cation in the Official Journal } \\
\text { of the European Union or at } \\
\text { a later date specified therein }\end{array}$ & $\begin{array}{l}\text { Рішення набуває чинності } \\
\text { на наступний день після } \\
\text { його публікації в Офіційно- } \\
\text { му віснику Європейського } \\
\text { Союзу, або на пізнішу дату, } \\
\text { вказану в рішенні }\end{array}$ & 3 & 1.1 \\
\hline
\end{tabular}


End of Table 1

\begin{tabular}{|l|l|l|l|c|c|}
\hline & $\begin{array}{c}\text { Means } \\
\text { of Translation }\end{array}$ & \multicolumn{1}{|c|}{ Source } & \multicolumn{1}{|c|}{ Target } & $\begin{array}{c}\text { Quan- } \\
\text { tity }\end{array}$ & \% \\
\hline 10 & $\begin{array}{l}\text { (Prep) + } \\
\text { Adj + N }\end{array}$ & $\begin{array}{l}\text { Spirit drinks which meet } \\
\text { the specifications for the } \\
\text { products defined in cate- } \\
\text { gories 1 to 46 of Annex II } \\
\text { shall bear in their descrip- } \\
\text { tion, presentation and } \\
\text { labelling the sales de- } \\
\text { nomination assigned } \\
\text { therein }\end{array}$ & $\begin{array}{l}\text { Спиртні напої, які відпо- } \\
\text { відають специфікаціям для } \\
\text { продуктів, визначених у ка- } \\
\text { тегоріях 1-46 додатка II, } \\
\text { повинні містити у своєму } \\
\text { описі, представленні та } \\
\text { маркованні торговельне } \\
\text { найменування, встановлене } \\
\text { у відповідній категорії }\end{array}$ & 3 & 1.1 \\
\hline \multicolumn{2}{l|}{ Total } & 264 & 100 \\
\hline
\end{tabular}

So, the most frequently used means of translation is possessive pronoun, which can be accounted for by the fact that the compound thereof is used more than other PAs. It also proves the grammatical connection between the source and target lexemes. The proposition 'of' is used here to state the possessive relations between the objects, the whole PA meaning 'of this, of that, of these, of those' express genitive case in the meaning of possession. In Ukrainian we find possessive pronouns or nouns in genitive case to render the same.

\section{Conclusions}

To conclude with, the paper studied specific features of English pronominal pronouns and their translation, and the results of the research showed that the compounds in question are archaic feature of the English legalese. They appeared in the Old English period, the same time as the adverbs here and there emerged, and some of them came into use in the Middle English time. It means that the pronominal features were acquired by the compounds in the early years, though their primary meaning of "place" is common for both adverbs. The pronominal feature of the compounds in question is proven by the fact that here-/ there-element is a substitute of the name of the document (here) or the noun/ noun phrase (there), the PAs may perform the functions of attribute and object, usually performed by nominative word-groups (nouns, pronouns, adjectives). Moreover, the pronominal character of PAs is clearly seen through the lens of Ukrainian translation where they are mostly rendered by means of pronouns or noun phrases. Since Ukrainian does not have direct equivalents for English PAs, we can see ten different means used to translate them into Ukrainian. Still, there are several aspects that need further studying, such as the development of the PAs in legal English within the democratization of English legalese. It is worth 
studying the correlation of the case system in Ukrainian and the use of prepositions in English, and PAs and their translation may be of great importance for improving the translation of European legal acts into Ukrainian.

\section{References}

Carlo di, G. (2015). Diachronic and Synchronic Aspects of Legal English: Past, Present and Possible Future of Legal English. Cambridge: Cambridge Scholars Publishing.

El-Farahaty, H. (2011). Problems of Translating Legal Discourse with Special Reference to the United Nations Documents (PhD thesis). Leeds: University of Leeds.

Gentzler, E. (2001). Contemporary Translation Theories. Clevedon: Multilingual Matters Ltd.

Ludiková, M. (1987). On the Semantics of Pronominal Adverbs from the Quantitative Aspect. In Eva Hajičová, Ján Horeckỳ, \& Marie Těšitelová (Eds.), Prague Studies in Mathematical Linguistics (9, pp. 53-64). Amsterdam, Philadelphia: John Benjamins Publishing Company.

Newmark, P. (1981). Approaches to Translation. Oxford: Pergamon.

Ozhohan, V. (2016). Transpozytsiia nezaimennykovykh sliv do zaimennykovykh [Transposition of non-pronominal words into pronominal ones]. Naukovyi visnyk Khersonskoho derzhavnoho universytetu [Academic Journal of Kherson State University], 16-21 [in Ukrainian].

Pavliuk, N. (2012). Contrastive Grammar of English and Ukrainian. Donetsk: DonNU.

Qiqnqian, G. (2018). Cultural Frame and Translation of Pronominal Adverbs in Legal English. International Journal of Society, Culture \& Language, 6 (2), 113-124.

Vystrčilova, R. (2000). Legal English. Philosophica, 73, 91-96.

Zahnitko, A. P., \& Danyliuk, I. H. (2013). Korpus tekstiv hramatychnoi sluzhbovosti [Text corpus for grammatical auxiliary]. In Prykladna linhvistka ta linhvistychni tekhnolohii [Applied linguistics and linguistic technologies]: MegaLing-2012 (pp. 102-112). Kyiv: UMIF [in Ukrainian].

Наталія Павлюк

\section{ЗАЙМЕННИКОВІ ПРИСЛІВНИКИ В АНГЛІЙСЬКОМУ ЮРИДИЧНОМУ ДИСКУРСІ В УКРАЇНСЬКОМУ ПЕРЕКЛАДІ: СЕМАНТИЧНІ, МОРФОЛОГІЧНІ ТА СИНТАКСИЧНІ ОЗНАКИ}

У статті розглянуто особливості англійських займенникових прислівників та їхній переклад українською мовою. Результати дослідження показали, що ці складні лексеми є архаїзмами, що характерні для англійської юридичної мови, деякі з них з'явились у давньоанглійський період у той самий час, коли з'явились прислівники here, there, інші - у середньоанглійський період.

Метою цієї роботи є дослідити подвійну природу займенникових прислівників, що мають у своєму складі елементи here-/there-, 3 погляду їхніх семантичних, морфологічних та синтаксичних особливостей. 
Методи. Речення, які містять займенникові прислівники, що вивчаються, було вибрано з текстів методом суцільної вибірки. Для доведення займенникового характеру цих лексем використовували метод трансформаційного аналізу. Компонентний аналіз застосовано для вивчення семантики обох компонентів складних слів, описовий метод - для розкриття природи і походження цього мовного явища.

Результати. Займенникові прислівники з компонентом here-/ there набули займенникових ознак у давньоанглійський період, хоча позначення «міста» $є$ первинним як для 'here', так і для 'there', тобто прислівникова природа $є$ первинною. В юридичній англійській мові доказом того, що компоненти 'here' i 'there' мають займенникові ознаки, $є$ той факт, що вони заміняють назву документа ('here') або іменник/іменникове словосполучення ('there'). Ці займенникові прислівники можуть функціонувати у реченні як означення і додаток, що зазвичай $є$ функціями номінативних частин мовлення (іменників, займенників, прикметників). Крім того, займенниковий характер цих утворень можна простежити через український переклад, де вони передаються зазвичай за допомогою займенників або іменникових словосполучень. Оскільки в українській мові немає прямих відповідників займенникових прислівників, можна спостерігати вживання десяти різних способів їх перекладу українською мовою.

Обговорення. Після аналізу вживання займенникових прислівників у регламентах Європейської комісії та їх перекладів українською мовою, було зроблено висновки щодо використання цього архаїзму в документах $\mathrm{CC}$, а також виявлено всі способи передання їх засобами української мови. Найчастіше для перекладу англійських займенникових прислівників використовують присвійні займенники, що пояснюється тим, що thereof вживається більше за інші займенникові прислівники, а прийменник of є позначенням родового (присвійного) відмінку в англійській мові. Цей прийменник використовують для позначення присвійних відносин між об'єктами, а займенниковий прислівник має значення: «of this, of that, of these, of those», тобто виражає родовий відмінок у значенні присвійності. В українській мові таке значення мають присвійні займенники й іменники у родовому відмінку.

Ключові слова: юридичний дискурс, займенникові прислівники, юридична англійська мова, семантика, система відмінювання, архаїзм.

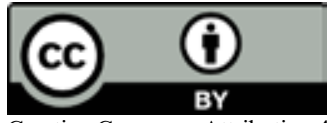

Матеріал надійшов 14.05.2020

Creative Commons Attribution 4.0 International License (CC BY 4.0) 